\title{
Analysis of Gender Role in Coffee Value Chain in Jimma Zone, Oromia National Regional State, Ethiopia
}

\author{
Fuad Kemal $^{*} \quad$ Bezabeh Emana $^{2} \quad$ Zekarias Shumeta $^{3}$ \\ 1.Haramaya University, college of agriculture and environmental science, School of agricultural economics and \\ business, P.O.Box 138, Haramaya, Ethiopia \\ 2.HEDBEZ Business and Consultancy PLC, P.O.Box 15805, Addis Ababa, Ethiopia \\ 3.Jimma University, college of agriculture and veterinary medicine, Department of Agricultural Economics and \\ Extension, P.O.Box 307, Jimma, Ethiopia
}

\begin{abstract}
This study aimed at analyzing gender role in coffee value chain in Jimma Zone with specific objectives of mapping gender sensitive coffee value chain and actor's role; analyzing determinants of women participation in coffee marketing. The value chain analysis revealed that the major actors were input suppliers, coffee producing farmers, collectors, suppliers, cooperatives/unions, exporters, domestic wholesalers, retailers and local consumers. Tobit models were used to analyze factors influencing intensity of women participation in coffee marketing. Factors determining quantity of coffee marketed by women were identified using Tobit model and; coffee area of the household, training and extension were among the significant factors that positively affected the intensity of women participation. Thus, targeting women in training and extension provision have paramount importance.
\end{abstract}

Keywords: Gender, Value chain analysis, Tobit

DOI: $10.7176 / \mathrm{EJBM} / 11-31-01$

Publication date: November $30^{\text {th }} 2019$

\section{INTRODUCTION}

Gender inequalities in society are recognized as one of the critical challenges impacting the attainment of sustainable development in the world. Despite several efforts by governments and non-governmental organizations (NGOs), gender inequalities still exist in almost all the countries in the world (World Bank, 2003). According to USAID (2009), gender issues affect and shape the totality of production, distribution, and consumption within an economy. In the value chain, all activities from production, processing to disposal reflect gendered patterns of behavior that condition men's and women's jobs and tasks. Gender relations at the household level play a key role in determining the extent to which men and women interact within a value chain. Degrees of participation and gains are shaped at the household level by gendered divisions of labour/time budgets and decision-making/control; and at the value chain level by differential access to services and resources, and by gender related power disparities in chain management. Distribution of the outcomes of the value chain is gendered and varies from place to place (Coles \& Mitchell 2011). Men tend to dominate functions with relatively high barriers to entry and correspondingly greater returns, and to control chain management functions while women occupy the lower nodes (Coles \& Mitchell 2011) due to lack of adequate income, limited skills, limited access to education and training, limited access to markets and market information (World Bank, 2007). Disproportionate representation of women in lowvalue value chains and the lower nodes within these chains is an established reality of value chains. Women tend to execute their productive and reproductive roles simultaneously (Bhattarai \& Leduc, 2009) causing women to engage mainly in value chain activities/nodes that allow them to be closer to the homestead, whereas men may freely engage in activities that require them to be away from home such as value chain nodes away from home, which are often more profitable. In coffee sector more than 100 million people are engaged in production and processing. $80 \%$ of the world's coffee is produced by 25 million smallholder coffee producers. Therefore making women visible, and making sure that they are served in agricultural value chains have massive benefits. This is especially so in value chains for major commodities such as coffee, where women do most of the work. Therefore, this study focused on analyzing gender role in coffee value chains

\section{RESEARCH METHODOLOGY}

\subsection{Description of the Study Area}

The study was conducted in two districts of Jimma zone of Oromia National Regional State of Ethiopia, namely, Mana and Seka-Chekorsa located at about $22 \mathrm{~km}$ and $20 \mathrm{~km}$ North-East and East of the capital of Jimma, respectively. Jimma is located at $330 \mathrm{kms}$ southwest of Addis Ababa. Maize, teff, sorghum, barley, wheat, coffee and horse bean are the most widely cultivated crops in the district. Coffee production of the area contributes significantly to the economic and social development including job opportunities for the people of the area and neighbor region (JZARDO, 2012). The livelihood of Mana and Seka-Chekorsa district is based on mixed farming and the main economic activities are crop production and livestock production. It has dominantly midland (Woina dega) agro ecology characteristics. 


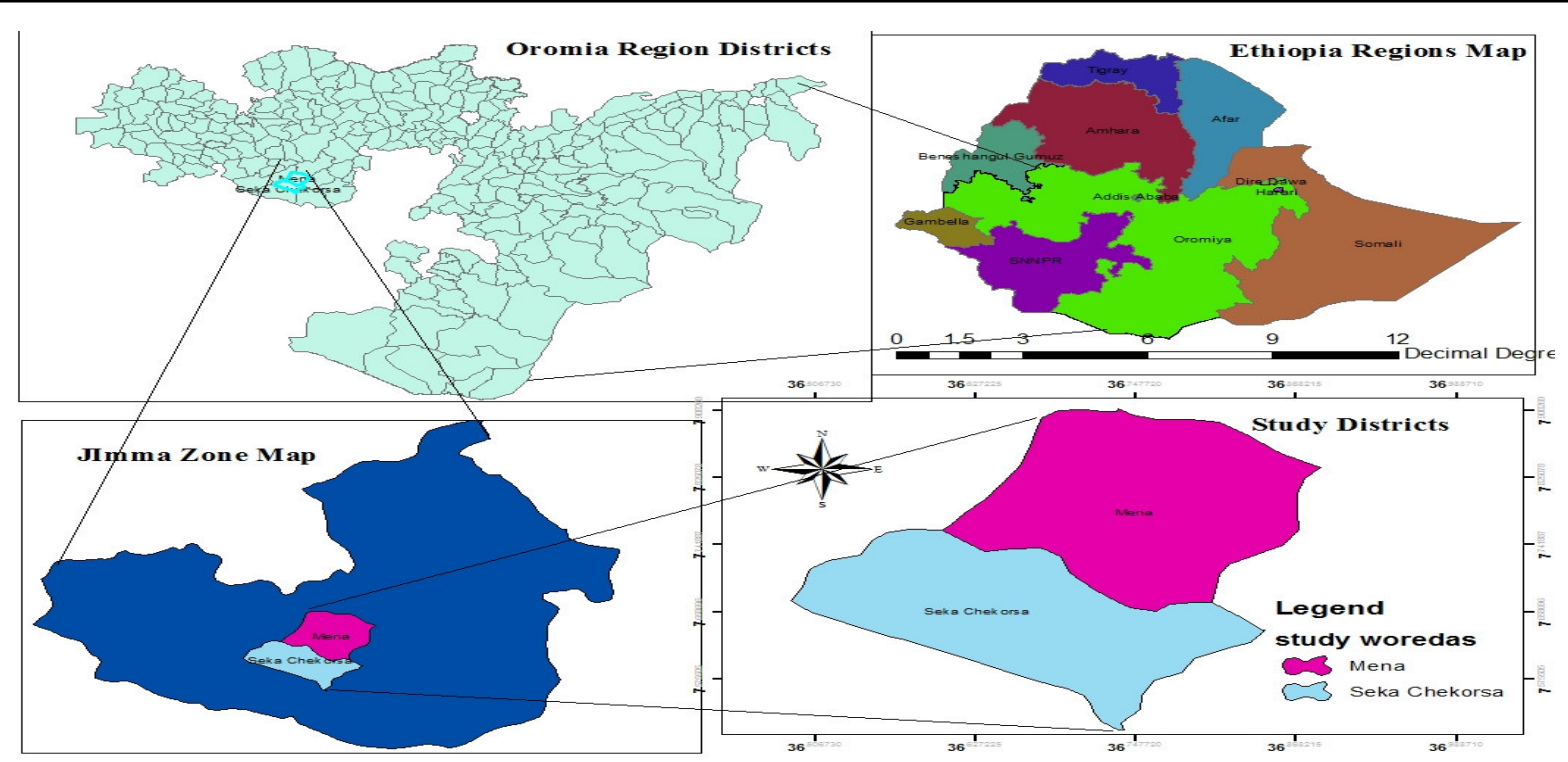

Figure 1 Geographical location of the study area

\subsection{Sample Size and Methods of Sampling}

Multi-stage sampling techniques were used to select districts, kebeles and farm HHs. In the first stage, the districts were selected purposively based on potential to coffee production. In the second stage, a total of 6 kebeles were selected randomly from the two districts ( 3 from each). Finally, a total of 215 coffee growing farmers were selected from the selected kebeles using random sampling techniques following probability proportional to sample size.

Table 1: Distribution of sample HHs across district and sampled kebeles HHs

\begin{tabular}{llllllll}
\hline \multirow{2}{*}{ District } & Kebeles & \multicolumn{3}{c}{ Number of households } & \multicolumn{3}{c}{ Sample households } \\
\cline { 3 - 8 } & & MHHs & FHHs & Total & MHHs & FHHs & Total \\
\hline Mana & Bilida & 690 & 62 & 752 & 32 & 3 & 35 \\
& KellaGuda & 1003 & 73 & 1076 & 46 & 3 & 49 \\
& GubeBosseqa & 1135 & 80 & 1215 & 52 & 3 & 55 \\
Seka- & EndadeAllaga & 500 & 45 & 545 & 22 & 2 & 24 \\
Chekorsa & SakebaGenefo & 597 & 45 & 642 & 28 & 2 & 30 \\
& Gibe Bosso & 433 & 38 & 471 & 20 & 2 & 22 \\
Total & & $\mathbf{4 3 5 8}$ & $\mathbf{3 4 3}$ & $\mathbf{4 7 0 1}$ & $\mathbf{2 0 0}$ & $\mathbf{1 5}$ & $\mathbf{2 1 5}$ \\
\hline
\end{tabular}

Sources: own survey results, 2016

There was no documented figure about other market actors especially input suppliers and collectors but by following the flow of the coffee they were identified, selected and presented on table 2 below.

Table 2: Distribution of sample size for actors different than producers

\begin{tabular}{lllll}
\hline Value chain actors & Total numbers & & Sample & \\
\cline { 2 - 5 } & Male & Female & Male & Female \\
\hline Input suppliers & - & - & 4 & 1 \\
Collectors & - & - & 6 & 0 \\
Suppliers & 44 & 4 & 7 & 4 \\
Exporters & 121 & 0 & 4 & 0 \\
Wholesalers & 24 & 4 & 10 & 4 \\
Retailers & - & - & 7 & 13 \\
Consumers & - & - & 8 & 14 \\
Total & & & 46 & 36 \\
\hline
\end{tabular}

Sources: own survey results, 2016

\subsection{Sources and Methods of Data Collection}

Both primary and secondary data were used for the study. The primary data were collected from major value chain actors using structured and semi structured questionnaires designed for each actor. The three main components of HAF (Harvard Analytical Framework) were employed for collecting gender disaggregated data at the community and household level. In addition to the major coffee value chain actors, service providers like Ethiopian commodity exchange (Jimma branch), District level administration bodies, development agents, credit and other financial service providers (Harbu saving and credit) were contacted. Focus group discussion was also held between farmers, 
gender expert and coffee experts at the respective district to acquire additional supporting information using checklists. Key informant interviews were also held with DAs, elders and peasant association representatives of the kebeles.

\subsection{Method of Data Analysis}

\subsubsection{Value chain analysis}

A) Mapping gender sensitive value chain

To illustrate the gender sensitive coffee value chain map, various procedures of value chain mapping were adopted as an analytical tool. The drawing of the value chain map goes through the following steps: In the first step the core processes of the value chain and main actors (men \& women) were identified and mapped with their respective activities. At the second step mapping flows of products, information, knowledge and support services for the value chain actors at different stage were mapped. Mapping the volume of products, numbers of actors and relationships and linkages between value chain actors were made at the third step because of the fact that some dimensions in value chain mapping can be quantified Mapping relationships and linkages between value chain actors were done.

B) Identifying distribution of benefits among chain actors

The benefits of the value chain actors were determined through the analysis of margins and profits within the chain.

C) Defining upgrading needed within the chain

An analysis of the upgrading process includes an assessment of the profitability of actors within the chain as well as information on constraints that are currently present then upgrading solutions will follow. These may include interventions to: (I) Improve product design and quality and move into more sophisticated product lines to gain higher value and/or diversify production and (II) Adapt the knowledge gained in particular chain functions in order to redeploy it.

D) Emphasizing the role of governance

Governance in a value-chain refers the structure of relationships and coordination mechanisms that exist between actors in the value-chain. The analysis identified actors that may require support to improve capabilities in the value chain, increase value added in the sector and correct distributional distortions.

\subsubsection{Econometric analysis}

To analyze determinants of women's participation level in coffee marketing at farm HH level Tobit model was used, which has both discrete and continuous part. Women in some household participate in coffee marketing, while in other household did not. The data collected tend to be censored at the lower limit of zero. The data have a censored sample as dependent variable; out of 215 samples, $17.7 \%$ of women didn't participate in coffee marketing even if the household was coffee producer. If zero values of dependent variables were the result of rational choice of farmers, a Tobit model would be more appropriate (Abrar, 2004).Thus, maximum likelihood Tobit estimation (Tobin, 1958) was used in the analysis or as well as the marginal effects. A Tobit model answers both the factors that influence the probability of market participation and intensity of participation by women. The Tobit model for the continuous variable, amount of marketed coffee by women can be defined as:

$$
Y_{i}^{*}=B_{0}+B_{i} X_{i}+e_{i}
$$

$$
Y_{i}=\left\{\begin{aligned}
Y_{i}^{*}, & B_{0}+B_{i} X_{i}+e_{i}>0 \\
0, & B_{0}+B_{i} X_{i}+e_{i} \leq 0
\end{aligned}\right.
$$

Where: $Y_{i}=$ is amount of coffee sold by women

$X_{i}=$ vector of factors affecting amount of marketed surplus $B_{i}=$ vector of unknown parameters and $e_{i}=$ is the error term which is normally distributed with mean zero and variance $\sigma^{2}$.

McDonald and Moffit (1980) proposed the following techniques to decompose the effects of explanatory variables into participation and intensity effects. Thus, a change in $\mathrm{X}_{\mathrm{i}}$ (explanatory variables) has two effects. It affects the conditional mean of $\mathrm{Y}_{\mathrm{i}}^{*}$ in the positive part of the distribution, and it affects the probability that the observation will fall in that part of the distribution. Similar approach is used in this study as well.

$>$ The marginal effect of an explanatory variable on the expected value of the dependent variable is given by:

$$
\begin{gathered}
\frac{\partial \mathrm{E}\left(Y_{i}\right)}{\partial X_{i}}=F(z) \beta_{i} \\
\text { Where: } \mathrm{z}=\frac{\beta_{i} X_{i}}{\sigma}
\end{gathered}
$$

The change in the probability of participation as independent variable $\mathrm{X}_{\mathrm{i}}$ changes is given by: 


$$
\frac{\partial F(Z)}{\partial X_{i}}=f(\mathrm{z}) \frac{\beta_{i}}{\sigma}
$$

The change in intensity of participation with respect to a change in an explanatory variable among participant here continued users is given by:

$$
\frac{\partial E\left(Y_{i} / Y_{i}^{*}>0\right)}{\partial X_{i}}=\beta_{i}\left[1-Z \frac{f(z)}{F(z)}-\left(\frac{f(z)}{F(z)}\right)^{2}\right]
$$

\section{RESULTS AND DISCUSSION}

\subsection{Gender Analysis}

Under this section household participation in different triple role (productive, reproductive and community role) and access and control over resources within HH are discussed. Table 3 indicated that men dominate activities which are considered as productive whereas women were concentrated at reproductive activities that can earn no cash whereas no difference was observed on community role.

Table 3: Household participation in triple roles (\%)

\begin{tabular}{lcccc}
\hline Activities & Men & Women & Boys & Girls \\
\hline Productive role & & & & \\
$\quad$ Ploughing & 80 & 1 & 19 & - \\
$\quad$ Sawing & 83 & 10 & 6 & 1 \\
Fertilize application & 47 & 38 & 7 & 8 \\
Weeding & 38 & 32 & 8 & 22 \\
Harvesting & 68 & 19 & 8 & 5 \\
Threshing & 70 & 18 & 5 & 7 \\
$\quad$ Transporting to homestead & 80 & 7 & 10 & 3 \\
$\quad$ Livestock production & 17 & 48 & 15 & 19 \\
Reproductive role & & & & \\
$\quad$ Food preparation & 5 & 60 & 7 & 28 \\
$\quad$ Fuel wood collecting & 6 & 50 & 10 & 34 \\
$\quad$ Water fetching & 3 & 53 & 6 & 38 \\
$\quad$ Rearing children & 4 & 60 & 6 & 30 \\
Community role & & & & \\
$\quad$ Soil and water conservation & 39 & 42 & 11 & 8 \\
$\quad \begin{array}{l}\text { Cooperation during wedding, sorrow } \\
\text { Maintenance of water, health and } \\
\text { other societies resources }\end{array}$ & 36 & 49 & 7 & 8 \\
Sour own survey rests, 2016 & 48 & 40 & 5 & 7 \\
\hline
\end{tabular}

Sources: own survey results, 2016

Household members participated on productive role with different extent, except ploughing land, which were undertaken by men and boys. On the other hand sawing and fertilizer application were mainly done by men and women. In weeding, women and girls constitute $32 \%$ and $22 \%$ respectively. Harvesting, threshing and transporting the produce to homestead were mainly men's job. Based on the above figure men share the highest responsibility, this was may be some tasks like ploughing and transporting demand physical strength. Table 3 also depicted that women's contributions in reproductive activities are much higher than that of their counter parts. It was because women were generally expected to fulfill the reproductive responsibilities of rearing children, household management tasks and home based production. In community role, men (39\%) and women (42\%) participated in conserving the area by participating in soil and water conservation program. In social coming together like weeding and sorrow women takes the front line in representing the family. These activities are undertaken as an extension of their reproductive role and are normally unpaid.

Access and control over resources and benefits within the $\mathrm{HH}$

Sampled HH possess different resources which belong to the HH so that member can access to and control over. Though the resources are belongs to $\mathrm{HH}$, the magnitude of accessing and controlling differ between men and women and presented in the following table. 
Table 4: Gender disaggregated access to and control over resources/benefit within HH (\%).

\begin{tabular}{lcccc} 
& \multicolumn{2}{c}{ Access } & \multicolumn{2}{c}{ Control } \\
\cline { 2 - 5 } \multicolumn{1}{c}{ Resources and benefits } & Women & Men & Women & Men \\
\hline Land & 50 & 50 & 28 & 72 \\
Farming equipment & 48 & 52 & 33 & 67 \\
Home equipment & 55 & 45 & 64 & 36 \\
Labor & 45 & 55 & 30 & 70 \\
Farming income & 33 & 67 & 30 & 75 \\
Non-farming income & 38 & 62 & 27 & 73 \\
Training & 25 & 75 & 25 & 75 \\
Credit & 40 & 60 & 38 & 62 \\
Cooperatives & 2 & 98 & 2 & 98 \\
Idir & 50 & 50 & 50 & 50 \\
Political and community leadership & 20 & 80 & 20 & 80 \\
\hline
\end{tabular}

Sources: own survey results, 2016

Land is one of the major resources that HH depends on for their livelihood. Men and women had equal access to HH's land title which was guaranteed by low, but it was observed that men have more controlling power over the land. Similarly, on farming and home equipment and labor men and women had relatively equal access but men dominate controlling except home equipment. Although both men and women have had access/participated on generating income for the $\mathrm{HH}$, but men tend to control over income obtained from both farming and nonfarming activities more than their access/contribution on generating the income. The result indicated that men had relatively more power on controlling farming income (75\%) and non-farming income (73\%). Table 4 also shows that women's access to or participation in institution were minimal except in Idir in which they have equal access and controlling over. Training participation, leadership role in community and political affairs of women was by far lower than that of men as shown in table 4. Cooperative is one of the institutions that men solely dominated. This is due to the fact that only head of the household which the husband unless for women headed household, women in a family cannot be direct members.

\subsection{Value Chain Analysis}

3.2.1. Mapping gendered coffee value chain

The coffee value chain illustrated in Figure 2 shows actors participating in value chain and performing value adding activities in production, processing and marketing stages of the coffee value chain. The direct actors identified in the coffee value chain were input suppliers, smallholder producers, cooperatives, unions, suppliers, exporters, domestic wholesalers, domestic retailers and local consumers. These are firms and individuals who assume different function in the value chain, engaging directly in production, processing, trading and marketing. They become the owner of the product and/or take active market position. Each of these actors adds value in the process of changing product title. Some functions are performed by more than one actor, and some actors perform more than one function. Other indirect enabling institutions identified as supporting coffee value chain are banks, cooperatives, unions, Oromia credit and saving institute, DOA, microfinance institutions and ECX. 


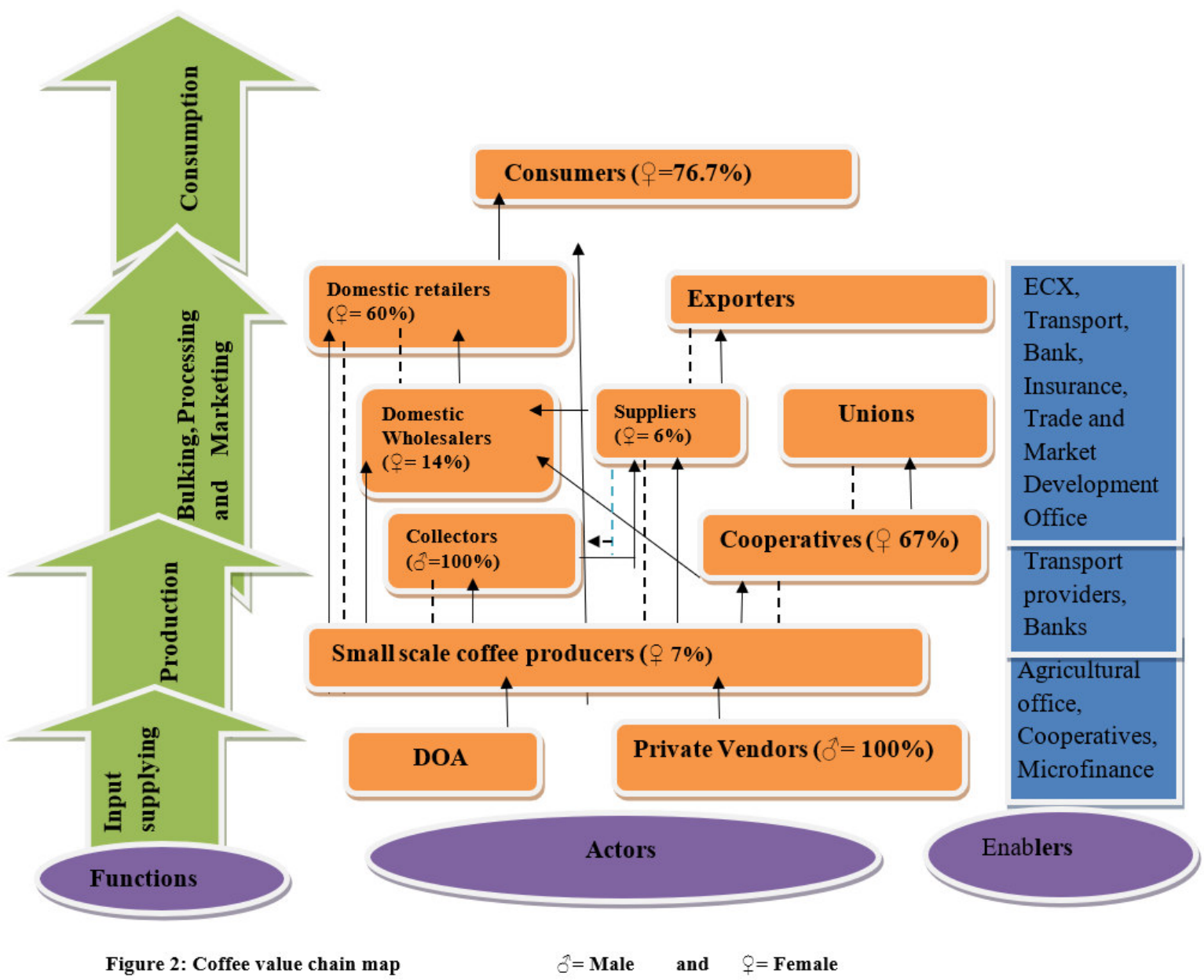

\subsubsection{Actors and their functions in coffee value chain}

The value chain map highlighted the involvement of diverse actors who are participated directly or indirectly in the value chain. According to KIT et al. (2006), the direct actors are those involved in commercial activities in the chain (input suppliers, producers, traders, consumers) and indirect actors are those that provide financial or non -financial support services, such as credit agencies, business service providers, government, NGOs, cooperatives, researchers and extension agents.

\section{Input supplier}

District level agricultural offices (DOA), primary cooperatives and private input suppliers were participated in supplying inputs for the farmers. Coffee seedling, manure, compost, fertilizers, and pesticides are the major inputs used for coffee production in the study area. The above major inputs are also prepared and used by some farmer. Extension officers also help in supplying the inputs or link the farmers to DOA. Traders in input supply in the villages surveyed is dominated $(100 \%)$ by men who can easily travel long distances to purchase them from whole sellers located in Jimma town.

Out of 155 input users, $24.7 \%$ of them used compost made at home and the one obtained from other farmers and $19.5 \%$ manure prepared at their backyard for coffee production. To fulfill their seedling need $14 \%$ of farmers obtained from DOA and private vendors. Around 28\% (25\% men and 3\% women) responded that they had not applying any yield improving inputs for their coffee plantation. The reason indicated were knowledge gap on how to prepare the above organic fertilizers, shortage of supply and its high price.

\section{Table 5: Input used and their sources}

\begin{tabular}{lcccccc}
\hline Inputs used & Frequency & $\mathbf{\%}$ & Source of inputs & \multicolumn{3}{c}{ Responsible person (\%) } \\
\cline { 5 - 8 } & & & & Men & Women & Jointly \\
\hline Compost & 53 & 24.7 & Own \& other farmers & 45.2 & 40 & 14.8 \\
Manure & 42 & 19.5 & Own & 33 & 67 & 11 \\
Seedling & 30 & 14 & DOA and Private Vendors & 100 & 0 & \\
Compost and Manure & 30 & 14 & Own & 32 & 48 & 20 \\
\hline
\end{tabular}

Sources: own survey results, 2016

Small scale coffee producers of the area used organic fertilizer for coffee production especially those who are 
a member of cooperatives and women play a critical role in preparing these inputs. From the total $155 \mathrm{HH}$ of input users, $67 \%$ of them responded that women prepare livestock manure and made ready for its application which then applied by men. HH (48\%) who applied compost and manure in combination reveled that women were responsible on preparing compost using coffee pulp and husk and manure using livestock wastes. Around $14 \%$ of the household bought seedling from DOA and private vendors to substitute their old coffee trees and men were responsible to undertake this activity.

\section{Producers}

There was around 42,278 smallholder coffee producers in the study area and 215 were sampled for this study. They are the major actors who perform most of the value chain functions right from farm inputs preparation to post harvest handling and marketing. The major value chain functions that coffee producers perform include land preparations, plowing, seeding preparation, weeding, and pest/disease controlling, harvesting, processing and marketing.

Out of 215 sampled coffee producers, FHH account $7 \%$ and the rest $93 \%$ are headed by male with an average land holding of 0.89 ha and 1.75 ha respectively. Men are involved in all the activities done by women and so are the women in the so called "men's activities": gender differences are observed in their extent of involvement in different tasks. An average of $560 \mathrm{Kg}$ of coffee was sold in 2016 by the household both by men and women. Out of the $560 \mathrm{Kg}$ coffee sold, around $110 \mathrm{Kg}$ of coffee was sold by women.

\section{Gender participation on coffee production}

Under this section participation of HH members in coffee production and marketing was discussed in detail. It underlines the participation by each $\mathrm{HH}$ members on each activity undertaken at $\mathrm{HH}$ level in which coffee passes through from seedling preparation to marketing.

Table 6: Proportion of HH participates in coffee production and marketing (\%)

\begin{tabular}{llllll}
\hline \multirow{2}{*}{ Activities } & \multicolumn{5}{c}{ Participants (\%) } \\
\cline { 2 - 6 } Seedling preparation & Men & Women & Boys & Girls & Hired labor \\
Transplanting seedling & 17 & 42 & 8 & 33 & - \\
Hoeing & 18 & 50 & 12 & 20 & - \\
Weeding & 49 & 11 & 38 & 2 & - \\
Coffee cherry collecting & 17 & 44 & 14 & 25 & - \\
Cleaning & 26 & 24 & 23 & 22 & 5 \\
Drying & 21 & 39 & 14 & 26 & - \\
Hulling & 20 & 35 & 15 & 30 & - \\
Grading/sorting & 16 & 32 & 8 & 24 & 20 \\
Transporting to the market & 23 & 28 & 8 & 7 & - \\
Selling coffee & 48 & 18 & 29 & 5 & - \\
\hline Sources: own survey results, & 60 & 14 & 20 & 6 & - \\
\hline
\end{tabular}

Sources: own survey results, 2016

Table 6 indicates that participation of $\mathrm{HH}$ members in coffee production varies across activities. Seedling preparation was the responsibility of women and girls as they represent $42 \%$ and $33 \%$ of the HHs respectively in handling this activity. Moreover $50 \%$ and $20 \%$ of the $\mathrm{HH}$ stated that women and girls are responsible for transplanting of seedling to farm plots respectively. This implies that in the study area women and girls are playing a major role in both seedling preparation as well as transplanting it. Hoeing the land is fallen on men's (49\%) and boys' (38\%) shoulders due to its demand for physical strength. Women and girls participated in weeding the coffee field intensively where $44 \%$ and $25 \%$ of them involved in such activities, respectively.

As coffee production is a family business, all family members participated in each activity and the extent of participation was almost similar in coffee cherry collecting. The proportion of men, women, boys and girls who involved in coffee cherry collection was $26 \%, 24 \%, 23 \%$ and $22 \%$, respectively. The reason indicated for polling family members' force were labor intensiveness of the activity, those with large family size benefited by using the available resources (labor) and those with small family size cover their labor need by hiring laborers $(5 \%)$.

In cleaning and drying activities women and girls take the major share. For cleaning coffee; 39\% of women and $26 \%$ of girls were involved and after primary cleaning, women $(35 \%)$ and girls $(30 \%)$ continue their significant contribution by drying the coffee. They dried coffee cherries on bamboo bed, mesh wired bed and cement floors after conducting primary sorting and grading. Here drying coffee was considered as women's task. Out of 215 coffee producers, about $20 \%$ of them hired labor to hull the coffee in which all of these casual laborers were women. Coffee hulling is dominated by female counterparts. Those sample coffee producers who perform the activity using family labor, pointed that around $16 \%$ of men, $32 \%$ of women, $8 \%$ of boys and $24 \%$ of girls were participated in hulling coffee.

Before the collected red cherry is transported to the market, farmers undertake farm level sorting and grading activities. The result showed that men $(23 \%)$ and women $(28 \%)$ are the major participants of sorting and grading. High participation of men and women in the sorting and grading activity is attributed to experience or better know 
how of grading or sorting the coffee. At this level, good quality coffee was separated from the poor one.

Transportation was also another function performed by the producers. Coffee producers used different mode of transportation to move their produce from farm to home and/or to market. They predominantly used pack animals, animal-cart and vehicles to transport coffee. Transporting coffee to market place was mainly undertaken by male. The labour division shows that men (48) were dominant actors in coffee transporting followed by boys $(29 \%)$ and women $(18 \%)$. Only few girls $(5 \%)$ were involved in coffee transporting. Despite the fact that women conduct a substantial part of the work on a coffee farm, it is the men who market the coffee and control the income from the coffee sales. The result showed that $60 \%$ of men and $20 \%$ of boys were participated in marketing coffee, leaving the other members to insignificant level of participation.

\section{Local collectors}

These are traders who collect coffee from farmers in village markets and farmer's farm for the purpose of reselling to suppliers. In 2016they bought around $24730 \mathrm{Kg}$ of coffee from farmers and resell to suppliers. Collectors and farmers present their coffee at collection stations which are around a total of 213 coffee marketing centers in the study area. Representatives of coffee merchants (wholesalers) and primary cooperatives buy/collect coffee at each station. There are many collectors who were all male, directly bought the coffee with its pulp (Jenfel coffee) and/or without pulp and sold it to suppliers for further processing activities and preparation for marketing. Collectors add value by bulking and transporting coffee by using animal pack to their respective suppliers.

\section{Cooperatives}

Primary cooperatives are the major actors which purchase coffee directly from smallholder farmers which account $29 \%$ of coffee marketed by sampled producers. There are more than 16 primary coffee cooperatives in the study area with an average of 155 (111 male and 44 female) members. Cooperatives undertake coffee processing (wet and dry) and marketing function. In wet processing, immersion of coffee in the water to be sorted, pulping, soaking and drying are the major activities. To accomplish the process 25 men and 50 women were hired. Women's role was concentrated on drying coffee rather than washing. The reason behind was all activities except drying were performed at night time and also laborious task which is not preferable by women. Women are under-represented in the cooperative and because of their limited networks; female producers have difficulty of successfully marketing and optimizing their income from coffee.

\section{Cooperative Unions}

The unions' functions are varied, and include exporting its members' produces, providing a warehouse service, promoting coffee processing, ensuring supply of organic coffee, supplying its members with modern inputs, providing transport for produce, educating its members with basic consumer goods at wholesale prices and representing its members. Participation of women in managerial roles was quite low, only 1 to 2 was women in a committee of 13 persons.

\section{Suppliers}

Suppliers are mainly involved in buying coffee from collectors and producers in larger volume than any other actors and supplying them to exporters and domestic wholesalers. The survey result indicates that suppliers bought $41 \%$ of coffee produced in their respective surrounding areas in 2015/16. There were 48 registered suppliers who actively worked in 2016 and only $6 \%$ of them were women. They bought $24730 \mathrm{Kg}$ and $95423 \mathrm{Kg}$ of coffee from collectors and producers respectively either at primary market center and/or at farm gates. They processed the coffee at coffee milling house which was dominated by women before they supplied to ECX auction market. After sorting and grading functions was performed by ECX, they receive a receipt which contains information about the grade and amount of coffee from ECX warehouse system for selling coffee at an auction., the first grade coffee was sold to exporters and the remaining lower grades to local merchants. At ECX, primary grading was undertaken by women to separate different grade of coffee presented by suppliers.

\section{Exporters}

They are private firms that purchase coffee from suppliers through ECX to sell in the export market. Currently, there are 121 registered coffee exporters participating in buying coffee from suppliers. They play a significant role by searching foreign market through the linkage they have with the importers outside the country. They add a place utility to the commodity coffee. Once exporters purchase coffee from suppliers, they sort it by color and polish the coffee before exporting to international market. Coffee that does not meet export standard is sold in the domestic market to wholesalers through ECX auction for rejected coffee.

\section{Domestic wholesalers}

Domestic wholesalers are value chain actors who directly buy coffee from producers and low standard coffee from suppliers and cooperatives and sell it to retailers. There are a total of 28 wholesalers out of which 4 of them were women. They bought around $28000 \mathrm{Kg}$ of coffee which was $17000 \mathrm{Kg}, 3400 \mathrm{Kg}$ and $7600 \mathrm{Kg}$ from producers, cooperatives and suppliers respectively in 2015/16. They sold the coffee to the retailers found at Jimma town and to other region of the country, where coffee is not grown at larger quantity. 


\section{Local retailers}

There are many merchants retailing coffee side by side with other commodities but only 25 (10 men and 15 women) retailers were contacted both at district and zonal level. They handled $7 \%$ of the coffee produced by producers $(16300 \mathrm{Kg})$ and $100 \%$ of wholesaler's coffee. The retailer's function in the chain includes buying of coffee, transport to retail shops, grading, displaying and selling to consumers. Retailers are key actors in coffee value chain in both districts. They are the last link between producers and consumers. They mostly buy from wholesalers and sell to urban consumers. Sometimes they could also directly buy from producers. Consumers usually buy the coffee from retailers as they offer according to requirement and purchasing power of the buyers.

\section{Local consumers}

They are the final actors who participate in coffee value chain. It was difficult to identify their numbers and 20 (17 women \& 3 men) cup coffee makers and 10 (6 women and 4 men) household consumers were contacted as key informants. They bought coffee from retailers and directly from producers but most of the consumers especially cup coffee makers prefer to buy coffee directly from farmers because of its quality and price and women coffee producers were their main suppliers.

\section{Support Service Providers}

Support service providers are those who provide supportive services including training and extension, information, financial and research services. According to Martin et al. (2007), access to information or knowledge, technology and finance determines the state of success of value chain actors. DOA, primary cooperatives, Unions, micro finance, ECX and Banks are main supporting actors who play a central role in the provision of such services.

\section{Training and Extension Services}

Cooperatives and DOA were the main sources of training and extension provided to coffee producers in both Districts. There are 6 DAs ( 2 female) who actively participate in training and extension services to farmers. Men \& women farmers didn't get training as well as extension service proportionally and also on specific commodity (coffee). The survey result revealed that a total of 183 respondents $(121$ men \& 62 women) had contact with extension agents (i.e. $85 \%$ of total respondents). In $2015 / 16,70 \%$ of respondents (93 men \& 57 women) participated in training provided on management, marketing, harvesting of different agricultural commodities.

Table 73: Access to training and extension services (\%)

\begin{tabular}{llccc}
\hline \multicolumn{1}{c}{ Variables } & & \multicolumn{2}{c}{ Sex } & \multirow{2}{*}{$\chi^{2}-$ test } \\
\cline { 2 - 5 } & & Men & Women & $20.821^{* * *}$ \\
\hline Training participation & & 61.9 & 38.1 & $31.366^{* * *}$ \\
\hline Extension contact & & 66 & 34 & \\
\hline \multirow{2}{*}{$\begin{array}{l}\text { Frequency of extension contact } \\
\text { (in a year) }\end{array}$} & Once & 19 & 27 \\
\cline { 2 - 5 } & Twice & 33 & 9 & \\
\cline { 2 - 5 } & Thrice & 10 & 2 & \\
\hline
\end{tabular}

*** Significant at less than $1 \%$

Sources: own computation, 2016

Table 7 reveals that women constitute $38.1 \%$ of 150 respondents who participated in training in 2016 and the chi-square test revealed that there is a statistically significant difference on training participation between men and women at $1 \%$ level of significance. Out of 185 respondents who obtained extension provision, women made $34 \%$ of it. The result shows that the extension provision was in favor of men. Accordingly, the chi-square test revealed that there is a statistical significant difference in extension provision between men and women at $1 \%$ level of significance. The extension contact made by farmers was further analyzed using frequency of contact made per month because of its importance in enhancing farmers' attitude and knowledge.

Financial services provision: Credit and saving institute, cooperatives, friends and private lenders were identified as the potential and available credit sources for smallholder farmers. Farmers in the study area used both cash and in-kind credit from formal and informal credit sources. From total sampled households, only $122(56.7 \%)$ individuals (96 men and 26 women) took credit because of religious and other personal reasons like the interest rate, disinterest to take. They got credit from different sources, 50\% from relatives/friend, 27\% from local money lenders, $12.3 \%$ from credit and saving institute and $10.7 \%$ from cooperatives. Source of credit for suppliers, wholesalers, exporters, cooperatives and Unions during the study period were banks.

Ethiopian Coffee Exporters' Association (ECEA): ECEA represents over 80\% of Ethiopia's coffee exporters who have over $96 \%$ market share of the Ethiopian coffee export. The association provides different services to its members and serves as focal institution for the working and business relationship between government and its members; and its members and Ethiopian coffee importers.

Ethiopian Commodity Exchange (ECX): The basic function of ECX is to provide a centralized and standardized trading platform for coffee traders besides dealing with several commodities. The major services provided in ECX are grading services, warehousing and trading services. These activities are performed by fulltime technical experts and casual laborer. Women are the major labor sources in separating coffee when presented with different grades 
by coffee been owners. In liquoring, classifying by taste and appearance, washed and unwashed coffee as it arrives at auction and also giving clearance to exporters prior to export.

Coffee value chain governance

The interaction between firms along the coffee value chain exhibited some reflection of organization rather than being simply random. The study revealed that coffee value chain is governed when parameters require product quality, demand and price setting which have downward consequences to smallholder coffee farmers. International importers have had high governing power on Ethiopian exporters and then suppliers by determining product specification, price and volume. This in turn has downward effect on smallholder farmers. So women in the $\mathrm{HH}$ are responsible in selling the coffee left over because of its quality for retailer and local consumers. While setting the price of the product, power asymmetry between smallholder farmers and suppliers was visible in that the issue of price determination at the farm level is governed by suppliers. On the other hand, the governing power that importers have on Unions then Cooperatives was identified as having a positive effect on farmers mainly on improving quality and product differentiations like producing organic coffee and specialty coffee demanded by international market. Regarding women farmers especially those in $\mathrm{MHH}$ are not direct beneficiaries. This is due to the fact that unlike the men who are members of the cooperatives, women in a family cannot be direct members. Hence, any dividend that would be gained from coffee marketing by cooperatives again goes to men registered as members. In this regard, the problem goes back to membership criteria and land ownership. Cooperative members are expected to be those registered as household heads and tax payers in their names in the village.

\subsection{Econometric Result}

3.3.1. Tobit model results of level of women participation in coffee marketing

Tobit model specified in Equation 5 was used to identify factors affecting intensity (amount of coffee) of women participation in coffee market in the study area. The overall significance and fitness of the model was checked with the value of chi-square; Pro $>\mathrm{chi}^{2}=0.000$ which shows that the result is significant at less than $1 \%$ level of significance. The log pseudo likelihood value of -322.209 indicates that the assumption of null hypothesis that all predictors in regression model are jointly equal to zero is rejected at less than $1 \%$ level of significance. Parameter estimates of the Tobit model for measuring the intensity of women participation in coffee market are presented in Table 8 .

Table 8: Tobit model results of level of women participation in coffee marketing

\begin{tabular}{|c|c|c|c|c|c|}
\hline Variables & Coef. & $\begin{array}{l}\text { Std. } \\
\text { Err. }\end{array}$ & $\begin{array}{c}\text { t- } \\
\text { value }\end{array}$ & $\begin{array}{l}\text { Change among coffee sellers } \\
\frac{\partial E\left(Y_{i} / Y_{i}^{*}>0\right.}{\partial X_{i}}\end{array}$ & $\begin{array}{l}\text { Change in } \\
\text { Probability } \\
\underline{\partial F(z)}=f(z) \underline{\beta}\end{array}$ \\
\hline $\begin{array}{l}\text { Dependent } \\
\text { members }\end{array}$ & $\overline{-}^{-}$ & 0.0516 & -2.67 & -0.1371 & $\begin{array}{cc}\partial X_{i} & \sigma \\
-0.0137 & \end{array}$ \\
\hline Credit & 0.2703 & 0.1820 & 1.38 & 0.2525 & 0.0259 \\
\hline Sex & $2.6425 * * *$ & 0.6543 & 3.95 & 2.591957 & .0827709 \\
\hline Women age & 0.0023 & 0.0134 & 0.16 & 0.0021 & 0.0002 \\
\hline Age difference & -0.0179 & 0.0109 & -1.54 & -0.0168 & -0.0017 \\
\hline Head's education & 0.1203 & 0.1413 & 0.79 & 0.1126 & 0.0113 \\
\hline Women education & 0.2929 & 0.2086 & 1.32 & 0.2742 & 0.0275 \\
\hline Coffee area & $1.5623^{* *}$ & 0.5506 & 2.48 & 1.462312 & 0.1466 \\
\hline Coffee area by women & 0.3027 & 0.3011 & 0.96 & 0.2844 & 0.0272 \\
\hline Training & $0.4404 *$ & 0.2131 & 1.92 & 0.4127 & 0.0407 \\
\hline TLU & -0.0897 & 0.0843 & -0.98 & -0.0840 & -0.0084 \\
\hline Extension & $1.0738 * * *$ & 0.2097 & 4.29 & 1.005063 & 0.1007 \\
\hline Women association & 0.0441 & 0.2908 & -0.14 & 0.0413 & 0.0041 \\
\hline Market distance & $0.8577 * * *$ & 0.2787 & -2.78 & -0.8029 & -0.0805 \\
\hline $\begin{array}{l}\text { Distance to development } \\
\text { center }\end{array}$ & $\begin{array}{c}- \\
1.3269 * * *\end{array}$ & 0.4559 & -2.70 & -1.2421 & -0.1245 \\
\hline NONF_INC & $0.5205^{* *}$ & 0.2219 & 2.06 & 0.4833 & 0.0529 \\
\hline
\end{tabular}

$* * *$ Significant at $1 \%$ level of significance, $* *$ Significant at $5 \%$ level of significance,

* Significant at $10 \%$ level of significance

1 qt (quintal) is equivalent to 100 Kilogram 
Dependent household members: Presence of dependent HH members is negatively correlated with the intensity of women participation in coffee market at $1 \%$ level of significance. One unit increase of dependent $\mathrm{HH}$ members decreased the amount of coffee sold by women by $0.14 \mathrm{qt}$, keeping other variables constant. This implies that household with large number of dependent $\mathrm{HH}$ members reduce amount of coffee marketed by women because of the fact that women in study area are supposed to be in the HH to nurture children and caring old age $\mathrm{HH}$ members in addition to other $\mathrm{HH}$ activities.

Sex of head of the household (Sex): Sex of the HH is positively related with amount of coffee marketed by women at less than $1 \%$ level of significance. When women are head of the HH quantity of coffee marketed by women was increased by $2.6 \mathrm{qt}$, keeping other variables constant. Being head of the HH increases the probability of quantity supplied among the non-participant women by $8.3 \%$.This implies that being head of the HH boost level of women participation in coffee market due to the case that when women are in the position of heading the $\mathrm{HH}$ they undertake most activities including selling coffee but not in the case of MHH as they are offered the low quality or left out coffee during harvesting which were insignificant. Mamo \& Deginet (2012) found similar result with the presence finding and stated that sex of $\mathrm{HH}$ head has significant effect on whether or not a farmer participates in livestock market.

Coffee area of the household: Coffee area of the HH is positively correlated with the amount of coffee marketed by women at less than $5 \%$ significance level. A 1 ha increase of area covered by coffee increased the amount of coffee marketed by women by $1.5 \mathrm{qt}$, keeping other variables constant. Increment of coffee area of the HH by 1 ha, increases the probability of quantity supplied among the non-participant women by $14.7 \%$. This shows that being in the $\mathrm{HH}$ that has large area of coffee increases the amount of coffee marketed by women because of the fact that HH with large coffee area have plenty of coffee to be marketed by HH members including women. This in line with Elias (2005) who stated that one of the variables with positive effect on coffee supply was coffee area of the farmers land and also Poulton et al. (2001) suggests that land is an important factor in influencing farmer's decision to produce any cash crop.

Women Participation in training: Training participation is also another factor, which positively affects marketed surplus at $10 \%$ significance level. Participation in training increased quantity of coffee marketed by women by $0.41 \mathrm{qt}$, keeping other variables constant. Women participation in training increases the probability of quantity supplied among the non-participant women by $4 \%$. This implies that participation in training like marketing increases women's intensity of participation in coffee market because training enhanced women's awareness towards marketing. Gani and Adeoti (2011) found that training participation has positively influence farmers' level of market participation.

Women contact with extension agent: As hypothesized, contact with extension agents positively influenced the quantity supplied by women at $1 \%$ significance level. Frequency of women contact with extension agent increased quantity of coffee marketed by women by $1 \mathrm{qt}$, keeping other variables constant. Extension contact of women increased the probability of quantity supplied among the non-participant by $10 \%$. This implies that contacting extension agent increases quantity of coffee supplied by women due to the fact that women who have higher number of contact with extension agent have obtained more advisory service and acquired better marketing skills. This is in line with Gani and Adeoti (2011) who found that frequency of extension visit positively influence farmers' market participation and level of market participation. Rehima (2006) and Holloway et al. (2000) also found that contact with extension agent improve participation and volume of marketable surplus of pepper and dairy, respectively.

Distance from nearest market center: As hypothesized, distance from nearest market center negatively influenced the quantity of coffee marketed by women at $1 \%$ significance level. Distance from nearest market center decreased quantity of coffee marketed by women by $0.8 \mathrm{qt}$, keeping other variables constant. Remoteness of market center decreases the probability of quantity supplied among the non-participant by $8 \%$. This implies that distance from nearest market center decreases quantity of coffee marketed by women due to the fact that women who are far apart from nearest market center, in addition to incurring high transportation, limitations on how far women are permitted to travel to get to the market discourage women. This is in line with Ayelech (2011) who indicated that distance to market caused marketable surplus of avocado to decline. Similarly study by Marcel et al. (2005), on coffee producers indicate that selling to the market is more likely when the market is nearer.

Distance from development center: Distance from development center is negatively influenced the quantity supplied by women at 1\% significance level. Distance from development center decreased quantity of coffee marketed by women by $1.2 \mathrm{qt}$, keeping other variables constant. Remoteness of development center decreases the probability of quantity supplied among the non-participant by $12.4 \%$. This implies that distance from development center decreases quantity of coffee supplied by women because of women who are far from development center may have limited contact with extension agent to acquire advisory. This is in line with Geremew (2012) who stated that actual distance of households' home from extension service center negatively influences the probability decision to produce sesame.

Participation on non-farm income: In dissonance with a priori expectation; participation on non-farm income is 
positively related with quantity of coffee supplied by women at $5 \%$ significance level. Women participation in non-farm income generating activities increased the amount of coffee marketed by $0.5 \mathrm{qt}$, keeping other variables constant. Earning income from non-farm activities increased the probability of coffee supplied among the nonparticipant by $5.3 \%$. This implies that earning better income from non-farm activities like trading encourages women's intensity of participation in coffee market because of the HH evidenced women's capability in trading. It agrees with the results of Siziba et al. (2011) and Buzalem (2015) who revealed that off-farm income was positively related to the level of cereal sale and marketed surplus of coffee, respectively.

\section{CONCLUSION AND OUTLOOK}

\section{Summary and Conclusion}

The descriptive result shows that all family members participate in both crop and livestock production at different extent. In crop production men's contributes were higher than women's except weeding the field which was mainly undertaken by women. But there was different scenario in rearing livestock. Even if all members of the HH share the responsibilities, women play a prominent role in rearing and caring for livestock especially in poultry production.

The coffee value chain analysis revealed that the main value chain actors were input suppliers, coffee producing farmers, collectors, Suppliers, cooperatives/unions, exporters, domestic wholesalers and retailers and local consumers. There are also governmental offices as supportive actors who support coffee value chain directly or indirectly. Value chain supporters or enablers provide facilitation tasks like creating awareness, facilitating joint strategy building and action and, the coordination of support. The main supporters of the coffee value chain in the study areas are office of agricultural and rural development (DOA), District administrations, EXC, ECEA, Oromia saving and credit institution, informal credit suppliers and banks. The study concluded that men and women involved in coffee value chain either as a major actor or as daily laborer. Men's involvement was observed as major actor in each segment of the value chain where as women are concentrated in production part of the value chain by producing on their own field which was obtained as marriage gift by husband or family coffee. As a daily laborer in coffee business, women were mainly engaged in processing coffee in cooperatives and coffee milling houses. And also in ECX women were hired to separate different quality of coffee supplied by producers and traders.

Based on the Tobit model, the study identified determining factors of quantity of coffee marketed by women. The result indicated that Sex of the $\mathrm{HH}, \mathrm{HH}$ coffee land, training participation, frequency of extension contact and non/off farm income was the most important and significant variable influencing quantity of coffee marketed by women positively. However, dependent $\mathrm{HH}$ members, distance from market center and distance from development center affected quantity of coffee marketed by women negatively. The study concluded that these were due to burden in the $\mathrm{HH}$ and women are not allowed to go far distance without husband permission and most of the time husband did not give permission.

\section{Recommendation}

Based on the findings of this study, the following recommendations and policy measures could be made. Men and women enrolment in value chain should be recognized and special attention should be given for women to participate in value chain segment that can provide better payment and it is necessary to strengthen the channel in which producers supply coffee to cooperatives so that producers continue benefiting from it. Cooperatives enable larger value addition. But at the same time the criteria of being cooperative members should be revised to accommodate women counterpart.

Any attempt aimed at increasing market participation of women should focus on working on significant variables which play a prominent role in extent of women participation in coffee marketing either positively or negatively. Frequency of extension contacts and distance from development center were the positive and negative determinant improving extension system, and technical supervision and follow up must be strong. Strengthening of market extension (linking farmers with markets, building marketing capacity of farmers, etc.) is necessary. And it is necessary to take into account accessibility of the development center during its establishment.

Practitioners, government and NGOs involved in value chain development should strengthen farmers' organizations (cooperatives) to facilitate equitable access by rural producers to agricultural inputs and markets for their produce. It is also recommended that gender sensitive intervention strategies should be used in forming and strengthening producer and marketing groups to competitively participate in coffee value chain and increase women participation and benefits from coffee marketing.

\section{REFERENCES}

Abrar, S., (2004). Smallholder supply response and gender in Ethiopia: A Profit Function Analysis. Sheffield Economic Research Paper Series, 7: p2-18.

Ayelech, T., (2011). Market chain analysis of fruits for Gomma District, Jimma zone, Oromia National Regional State. MSc thesis presented to School of Graduate Studies, Haramaya University. p1 10. 
Bhattarai, B. \& Leduc, B. (2009). Engendering value chain development. Kathmandu, Nepal: ICIMOD.

Buzalem, A., (2015). Value chain analysis of coffee in limu-Kossaa Gomma districts of Jimma Zone, Ethiopia. MSc thesis presented to the School of Graduate Studies, Jimma University. p5.

Coles, C. \& Mitchell, J., (2011). Gender and agricultural value chains: A review of current knowledge and practice and their policy implications.

Elias, A., (2005). Economics of coffee bean marketing: A case study of Goma District in Jimma Zone of Ethiopia. M.Sc. Thesis presented to School of Graduate Studies of Alemaya University. p68.

Gani, B. and Adeoti, A., (2011). Analysis of market participation and rural poverty among farmers in northern part of Taraba State, Nigeria.J Economics, 2(1): p27-32.

Geremew, K., (2012). Analysis of smallholder farmer's participation in production and marketing of export potential crops: The case of sesame in Diga District, east Wollega Zone of Oromia regional state. A thesis submitted to the school of economics in partial fulfillment of the requirements for the degree of masters of Science (International Economics), Addis Ababa, University.

Holloway, G., Nicholson, C. Delgado, C., Staal, S. \& Ehui, S., (2000). How to make milk market: A case study from Ethiopian high lands. Socio-economic and Policy Research Working Paper 28. ILRI (International Livestock Research Institute), Nairobi, Kenya. p28.

KIT, Agri-ProFocus \& IIRR, (2006). Challenging chains to change: Gender equity in agricultural value chain development. Amsterdam, KIT Publishers, Royal Tropical Institute.

Mamo, G. and Degnet, A., 2012. Patterns and determinants of live stock farmers' choice of marketing channels: micro-level evidence. Ethiopian Economics Association, Addis Ababa, Ethiopia. p55.

Marcel, F. and R.V. HILL, 2005. Selling at the Farm gate or travelling to market. America Journal of Agricultural Economics, 87(3): p717-734.

March, C., Smyth, I. and Mukhopadhyay, M., 1999.A Guide to Gender Analysis Frameworks.Oxfam Print Unit.

McDonald, J.F. and R.A. Moffitt. 1980. "The use of Tobit analysis." Review of Economics and Statistics, 62(2): p318-321.

Poulton, C., R. Al-Hassan, G. Cadish, C. Reddy and L. Smith, 2001. "The Cash Crop versus Food Crop Debate" Crop Post Harvest Program, Issue Paper 3.

Rehima, M., 2006. Analysis of red pepper marketing: The case of Alaba and Siltie in SNNPRS of Ethiopia. MSc thesis presented to the School of Graduate Studies, Haramaya University. p105.

Tabachnick and Fidell, 1996.Using multivariate statistics $\left(3^{\text {rd }}\right.$ Ed.) New York: Harper Collins.

Tobin, J., 1958. Estimation of relationships for limited dependent variables.Econometrica, 26: p24-36.

USAID, 2009. Promoting Gender Equitable Opportunities in Agricultural Value Chains: A Handbook. USAID, 1300 Pennsylvania Avenue, New York, Washington, DC. p38.

World Bank. 2007. World development report 2008: Agriculture for development. Washington, DC, USA: World Bank 